\title{
Beacon in developmental biology
}

Cite as: CMAJ 2017 October 16;189:E1298-9. doi: 10.1503/cmaj.109-5460

Posted on cmajnews.com on September 27, 2017.

$\mathrm{T}$ he identification of the genes responsible for controlling cellular fate and embryonic development in mice has made Dr. Janet Rossant a beacon in the field of developmental biology. Her work pioneered techniques that allowed genes to be altered within embryos. It also accelerated avenues in the fields of stem cell biology and regenerative medicine.

She was awarded the 2015 Canada Gairdner Wightman Award, presented annually to a Canadian who has demonstrated outstanding leadership in medicine and medical science. Rossant was recognized "for her outstanding contributions to developmental biology and for her exceptional international leadership in stem cell biology and policy-making, and in advancing research programs for children's illnesses." Among her many accomplishments, Rossant was the founding director of the Ontario Institute for Regenerative Medicine and is the current president and scientific director of the Gairdner Foundation. She is also the emeritus chief of research at SickKids and senior scientist in the Developmental and Stem Cell Biology Program at the University of Toronto. Antonio Bruni recently interviewed Rossant about her career.

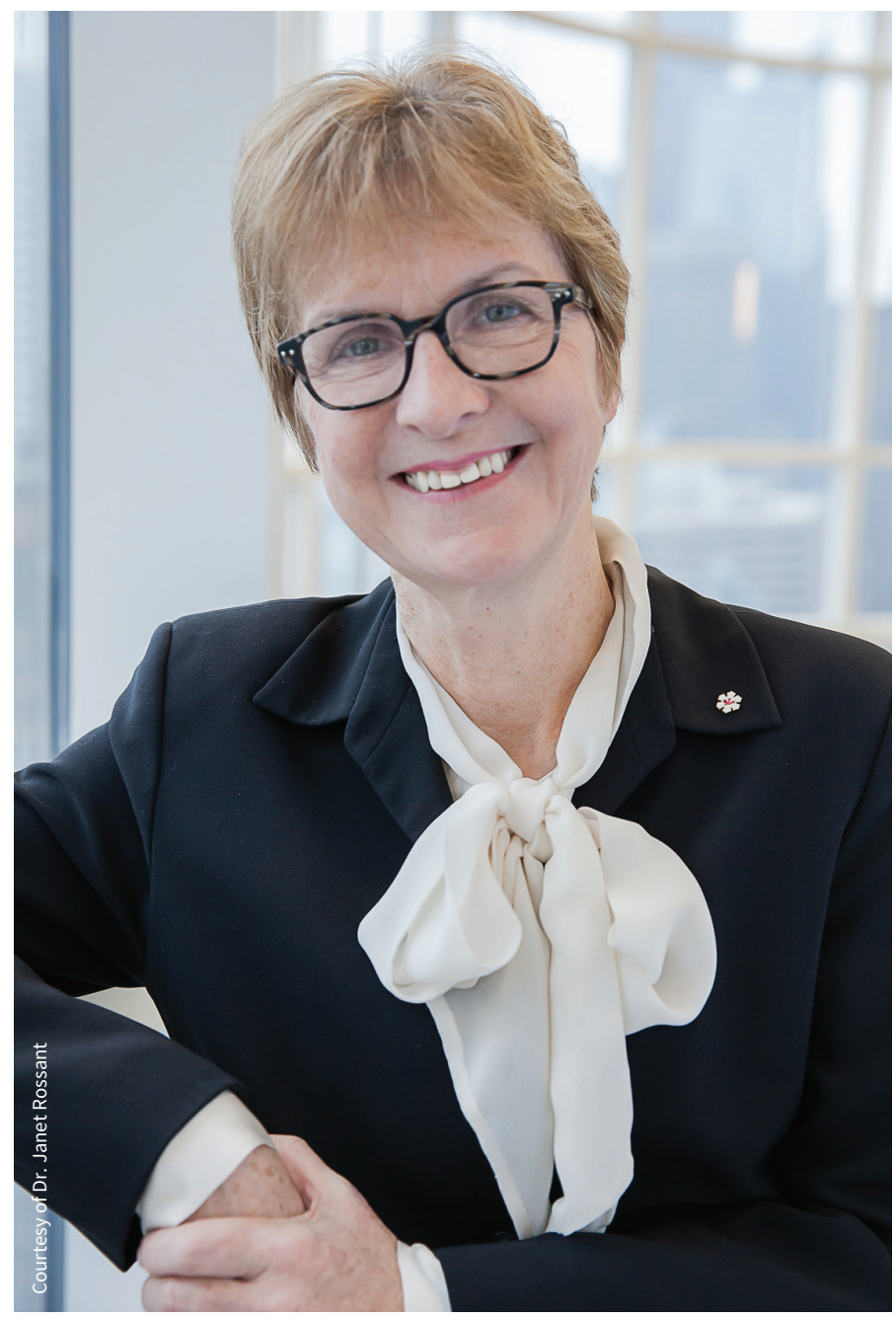

Dr. Janet Rossant work set a new course for altering genes within embryos.

Gurdon, whom some people may know recently received the Nobel Prize for his work cloning frogs; undertaking research that demonstrates that all of development is written in our genes, and all of our cells contain DNA that has that information, yet somehow during development, different genes are turned on and differentiation occurs. That's what really turned me on to the underlying problem of 'how do we get from a fertilized egg to an organism?' John is the person who really turned me on to that question and he has been pursuing it ever since and so have l."

For the diverse audience who read CMAJ, can you explain what stem cells are?

"Stem cells are cells that have the ability to selfrenew, make endless copies of themselves and yet also retain the potential to differentiate into specialized cell types. There are numerous stem cell types, including

Was there a defining moment in your life that sparked your interest in science, more specifically in developmental biology and stem cell research?

"When I was in high school, I had a great science teacher who certainly sparked my interest in science. When pursuing undergraduate studies at the University of Oxford, one of my lecturers was John pluripotent stem cells, which have the ability to differentiate into various cells. There are also adult-type stem cells, such as hematopoietic stem cells (which give rise to all other blood cells), the first stem cells to be described famously by James Till and Ernest McCulloch here in Canada. It is the self-renewal capacity of stem cells that really is their special property." 
What role has the study of developmental biology played in stem-cell research?

"Developmental biology in essence is the study of the egg-to-the-organism. It has played a role in stem-cell research in many different ways. The kind of research that I do is to understand how you go from the egg to the first stage of differentiation (the blastocyst) in a mammalian (mouse) embryo. That underlying research identified that the pluripotent cells that lie within the blastocyst give rise to the entire organism. Understanding the processes, growth factors and pathways that establish those cell types in the embryo allowed people to identify and isolate stem cells from blastocysts. First, in the mouse by Gail Martin, Martin Evans and Matthew Kaufman, and then in 1998 by James Thomson who isolated pluripotent stem cells from the human blastocyst. Shinya Yamanaka then took the information that we knew from development about the genes that specified pluripotency and was able to reprogram adult cells back to the early embryo. That is one aspect, identifying and understanding what pluripotent cells are. When you want to use pluripotent cells and differentiate them into cell types that you may want to use to study or treat disease for cell-based therapies, you have to understand how to make those cells go down specialized pathways - that is developmental biology, too!"

Despite great promise, there are still misconceptions related to stem cell research. What are some of the public's biggest misconceptions about stem cells and how has the public's perception changed throughout your career?

"The early work with human embryonic stem cells was ethically concerning because of the use of human embryos. The public at large was misled by many people into thinking that the work involved destroying babies, and of course, that is not the case. I think the public has a better understanding now of what embryonic stem cells are, and what their potential is. Another misconception that people have is that stem cells can cure everything. There has been a big push, a big hype worldwide, that stem cells could be used to cure everything, including stroke, cerebral palsy and autism, which has led to a proliferation of clinics worldwide claiming unproven therapies. That is a big concern, and it's a big concern for the stem cell community at large because the misuse of stem cell therapies could put the whole field in a bad light."

Among your many appointments, you currently serve as the president and scientific director of the Gairdner Foundation. What have been the biggest rewards and challenges of this role thus far?

"I have been the president of the Gairdner for one year, taking over from John Dirks who was the previous president for 22 years and did an amazing job in taking the Gairdner Foundation to where it is today as one of the leading prizes for biomedical research worldwide. The prestige of the Canada Gairdner International Awards, the Canada Gairdner Wightman Award, and the Canada Gairdner Global Health Award are all recognized internationally as the prizes that give a measure of the importance of research, and of course are also a precursor that hints that you may be going down the path to a Nobel Prize. It is an icon for Canada. I've learned a lot in my first year. In particular, I have learned how respected the Gairdner Award is by the international scientific community; it is seen as a prestigious award representing Canadian values, that Canada values science, excellence and evidence-based approaches."
As Canada's first female

Gairdner Wightman Laureate, what message would you give to encourage more women to pursue a career in the STEM (science, technology, engineering, mathematics) fields?

"I think that is interesting in itself, because what it says is that we still need to see more women coming into leadership roles in Canada and around the world. We have huge opportunities for students of all sorts of diversity, whether it is gender or ethnicity. We need to make opportunities available for everyone and I think that we are seeing a huge increase in the number of women coming into STEM careers; however, we are not seeing enough going through to the leadership level. Part of my role, as the leader of the Gairdner Foundation, is to make clear that women are just as successful and just as likely to succeed as men and that they are starting to do that in a big way. Through the Gairdner Foundation, we are trying to be part of the conversations about encouraging people to pursue STEM careers and use examples of people, such as myself, that it can be done and it may not be easy, but it's not easy going into any high pressure career. Science is a very rewarding career."

Antonio Bruni, Edmonton, Alta.

Editor's note: To commemorate the recent 30th anniversary of the Canadian Student Health Research Forum (CSHRF), four recipients of Gairdner awards gave public lectures highlighting their achievements. CSHRF participants were selected to interview the laureates. Antonio Bruni is a PhD candidate in the Department of Surgery at the University of Alberta in Edmonton studying islet transplantation as a treatment for type 1 diabetes in Dr. James Shapiro's laboratory. 